7. Пріма Р.М. Формування професійної мобільності майбутнього вчителя: вектори наукових досліджень / Р.М. Пріма // Педагогічна освіта: теорія і практика. Психологія. Педагогіка Збірник наукових праць № 25. - 2016. - С. 40-45

8. Брижак Н. Ю. Професійна мобільність як фахова якість майбутнього вчителя / Н. Ю. Брижак // Науковий вісник Ужгородського університету. - Серія: "Педагогіка. Соціальна робота". 2016. - Випуск 1 (38). - С. 67-70.

\title{
References
}

1. Sushentseva L.L., Sushentsev O.O. Vplyv profesiinoi mobilnosti na konkurentozdatnist fakhivtsia na suchasnomu rynku pratsi // Molodyi vchenyi, Pedahohichni nauky. - № 4 (31) kviten, 2016. - S. $568-572$

2. Prokhorenko T. H. Profesiina mobilnist yak faktor profesiinoi uspishnosti // T. H. Prokhorenko / Visnyk natsionalnoho universytetu "Iurydychna akademiia Ukrainy imeni Yaroslava Mudroho" № 4(35) - 2017. - S. 167-174

3. Pukhovska L.P. Profesiina pidhotovka vchyteliv u Zakhidnii Yevropi: Spilnist i rozbizhnosti: Monohrafiia/L.P.Pukhovska. - K.: Vyshcha shk., 1997.- $180 \mathrm{~s}$.

4. Piven N.V. Mizhdystsyplinarni zviazky dilovoi ukrainskoi movy z fundamentalnymy dystsyplinamy u pidhotovtsi bakalavriv tekhnichnoho profiliu / N.V.Piven // Pedahohika i psykholohiia profesiinoi osvity. - 2002. - №4. - S. 122-127.

5. Romanova S.M. Humanitaryzatsiia profesiinoi osvity u vyshchykh navchalnykh zakladakh tekhnichnoho profiliu SShA. Avtoref: dys... kand. ped. nauk: 13.00.04 - teoriia i metodyka profesiinoi osvity. /S.M.Romanova. - K., 1996. $-24 \mathrm{~s}$.

6. Bidiuk N.M. Rozvytok zmistu ta form orhanizatsii pidhotovky bakalavriv inzheneriv $\mathrm{v}$ universytetakh Velykoi Brytanii. Dys. kand. ped. nauk: 13.00.04 - teoriia i metodyka profesiinoi osvity / N.M. Bidiuk - K., 2001. - 179 s.

7. Prima R.M. Formuvannia profesiinoi mobilnosti maibutnoho vchytelia: vektory naukovykh doslidzhen / R.M. Prima // Pedahohichna osvita: teoriia i praktyka. Psykholohiia. Pedahohika Zbirnyk naukovykh prats № 25. - 2016. - S. 40-45

8. Bryzhak N. Yu. Profesiina mobilnist yak fakhova yakist maibutnoho vchytelia / N. Yu. Bryzhak // Naukovyi visnyk Uzhhorodskoho universytetu. - Seriia: "Pedahohika. Sotsialna robota". - 2016. Vypusk 1 (38). - S. 67-70.

Одержано статтю: 07.08.2019

Прийнято до друку: 21.08.2019

УДК 378.147:81.243

DOI: $10.15330 /$ esu. 16.198-205

\section{Уляна Кецик-Зінченко,}

кандидат педагогічних наук, доцент, ДВНЗ "Прикарпатського національного університету імені Василя Стефаника" (м. Івано-Франківськ, Україна)

Uliana Ketsyk-Zinchenko, Candidate of Pedagogical Sciences (PhD), Associate Professor, Vasyl Stefanyk Precarpathian National University (Ivano-Frankivsk, Ukraine) ulyanaket@gmail.com

\section{ВПЛИВ АНГЛОМОВНИХ ФАХОВИХ ТЕКСТІВ НА ВИВЧЕННЯ ТЕРМІНОЛОГІЧНОЇ ЛЕКСИКИ СТУДЕНТАМИ НЕМОВНИХ ФАКУЛЬТЕТІВ}

\author{
THE INFLUENCE OF PROFESSIONAL TEXTS IN ENGLISH ON STUDYING \\ TERMINOLOGICAL VOCABULARY BY STUDENTS OF NON-LINGUISTIC \\ FACULTIES
}

У статті наголошусться на важливому значениі іниомовного професійноорієнтованого читання у формуванні фахової іниомовної комунікативної компетентності y студентів немовних факультетів. Автор розкриває роль автентичних іниомовних 
фахових текстів у вивченні термінологічної лексики, володіння якою с основним критерісм знання фаху. Наголошується, ио вивчення іншомовної термінологічної лексики відповідно до фахової підготовки студентів, а відтак $і$ формувания їхньої іниомовної лексичної компетентності, буде тим успішнішим, чим краще зроблений відбір і методична класифікачія фахового матеріалу, який використовусться в навчальному прочесі. Розглянуто три етапи вивчения термінологічної лексики на базі англомовних фахових текстів; дається опис вправ, які застосовуються при опрачюванні термінів на кожсному етапі.

Ключові слова: професійно-оріснтоване читання, англомовні фахові тексти, термінологічна лексика, іноземна мова, іншомовна комунікативна компетенція.

The article deals with the problem of foreign terminological vocabulary studying by students of non-linguistic faculties of higher educational establishments. The author states that studying foreign languages at non-linguistic faculties is professionally directed. This means that the languages are taught in order to teach students to apply them in their professional activities to read special foreign literature for obtaining the necessary information, as well as be able to communicate with foreign colleagues on professional issues.

Teaching a foreign language to prospective specialists should be considered through the prism of their further professional activities. Some criteria of selecting terminological vocabularies (glossaries) for developing students' communicative skills and habits in the process of professionally oriented reading have been considered. The author reveals the role of authentic professional texts in forming professional foreign speech competence in future specialists. She has drawn the reader's attention to the necessity of differentiated approach in choosing authentic reading materials with the aim of further application in terminological vocabulary studying.

The basic criterion for student knowledge of his specialty is proficiency in professional terminology. Knowledge of terms in the profession is extremely important: sometimes the understanding of the content of the whole text depends on the correct understanding of one foreign term. Terminology vocabulary training is an important element in the process of foreign language studying. One way of mastering the terminology of the specialized field of future professional activity is to read original specialized texts.

The three stages of terminological vocabulary studying based on professional English texts are characterized in the article. The main exercises and tasks for mastering terms at each stage are given.

The author emphasizes that authentic professional texts are not only a main source for expanding terminological vocabulary of students, but also a means of formation and development of their professional skills, contribute to enhancing the culture of terminological communication.

Key words: professionally oriented reading, professional English texts, terminological vocabulary, foreign language, foreign speech communicative competence.

Постановка проблеми дослідження. В останні роки інтерес до оволодіння іноземною мовою (в першу чергу, англійською) значно зріс. Із розвитком засобів масової комунікації, особливо мережі Інтернет, професійна інформація стає більш доступною. Крім того, зростаючі ділові та культурні зв'язки із зарубіжними країнами вимагають, щоб сучасні фахівці володіли навиками читання документів, що супроводжують імпортну продукцію та послуги, могли самостійно здійснювати інформаційний обмін 3 іноземними діловими партнерами. Та, незважаючи на наявність потреби й усвідомленої мотивації в оволодінні англійською мовою, більша частина випускників вищих навчальних закладів не в змозі користуватись нею у своїй професійній діяльності. Саме тому все більше уваги приділяється врахуванню фахової специфіки при вивченні іноземної мови, їі спрямованості на реалізацію завдань професійної діяльності. Відповідні нові вимоги висуваються до методики викладання іноземних мов на немовних факультетах вишів. 
Наведені обставини роблять актуальним розвиток навичок роботи 3 професійно-орієнтованими текстами в процесі навчання студентів термінологічної лексики. Вивчення іншомовної фахової термінології на немовних факультетах $\epsilon$ важливим сегментом загального процесу підготовки фахівця відповідного рівня і профілю, компетентного i конкурентоспроможного на ринку праці. Іншомовне професійно-орієнтоване читання $\epsilon$ складовою частиною діяльності фахівців різних галузей.

Аналіз останніх досліджень і публікацій. За останні десятиліття у контексті проблеми, що розглядається, було проведено велику кількість наукових досліджень. Низку фундаментальних праць 3 навчання іншомовного читання виконано Г.В.Барабановою, Т.С.Сєровою, С.К.Фоломкіною. Методику навчання самостійного читання іншомовних текстів розроблено М.А.Алієвою, Н.М.Магазовою, І.Д.Трофімовою. Проблему вивчення фахової лексики розглядали у своїх працях науковці: Д.С.Лотте, Т.Л.Канделакі, В.П.Даниленко, Г.О.Винокур, К.Я.Авербух, В.І.Карабан та інші. Проблемами термінології глибоко займались такі лінгвісти, як Г.О.Винокур, А.А.Реформатський, О.С.Ахманова, В.П.Даниленко, Н.З. Котелова, С.В.Гриньов. Методологічні засади вивчення термінології досліджуються в наукових працях Т. І. Панько, З. Куньч, Ю.А.Зацний, Т.О.Пахомової, О.В.Столярської, О.О.Баловнєвої. Аспекти викладання фахової мови, застосування ефективних новітніх методик у роботі із термінологією досліджували І.М.Берман, К.Ф.Кусько, С.К.Фоломкіна, Ю.О.Семенчук, У.Ю.Жирик та інші.

Мета і завдання статті: розкрити роль іншомовних професійно-орієнтованих текстів у вивченні фахової термінології; розглянути етапи опрацювання термінологічної лексики на базі англомовних фахових текстів.

Виклад основного матеріалу. Вивчення іноземних мов у немовних вищих навчальних закладах $€$ професійно спрямованим. Це означає, що мови викладаються 3 метою навчити студентів застосовувати їх у своїй професійній діяльності, тобто читати спеціальну іншомовну літературу для отримання потрібної інформації, а також уміти спілкуватись із зарубіжними колегами 3 професійних питань.

Програма 3 іноземної мови для немовних вищих навчальних закладів передбачає оволодіння вмінням пошуку інформації для професійно орієнтованого читання та аналізу англомовних джерел [5, с. 54].

Проблема вивчення термінологічної лексики була $\mathrm{i} \epsilon$ актуальною у сучасній методиці. Цілком справедливо вважається, що навчання фахової термінології $\epsilon$ важливою ланкою у досягненні головної мети навчання студентів англійської мови. Одним із шляхів оволодіння терміносистемами спеціалізованої сфери майбутньої професійної діяльності є читання оригінальної літератури за фахом. Очевидно, що вивчення термінологічної лексики при викладанні іноземної мови професійного спрямування буде тим успішнішим і ефективнішим, чим краще зроблений вибір іншомовного фахового матеріалу, який використовується у навчальному процесі.

За твердженням К.Я.Кусько, “текст за фахом - це передусім засіб становлення та розвитку професійної, точніше мовно професійної майстерності” [4, с. 17]. На важливість правильного підбору текстів вказує і С.К.Фоломкіна. На иї думку, текст виступає "як основна комунікативна одиниця, якою користується людина в мовленнєвій діяльності" [5].

Однією 3 особливостей вивчення мови професійного спрямування $є$ те, що вона має бути максимально наближена до реальної професійної діяльності майбутнього фахівця. Основний критерій знання свого фаху - володіння професійною 
термінологією. Знання термінів у професії $є$ надзвичайно важливим: від правильного розуміння іншомовного терміна іноді залежить розуміння змісту всього тексту, оскільки саме терміни несуть у професійних текстах головне інформаційне навантаження.

Тексти фахового спрямування $\epsilon$ джерелом для розширення фахового термінологічного словника, предметом читання та обговорення на заняттях, основою для використання в ситуаціях мовлення, для аудіювання, тобто для цілеспрямованої і продуктивної мовленнєвої діяльності студентів.

Щоб запобігти можливим помилкам та головним труднощам, пов'язаним не просто з перекладом окремих термінів, зафіксованих у термінологічному словнику, а 3 передачею правильного змісту кожної фрази, якому не завжди відповідає дослівний переклад, викладачу потрібно ознайомити студентів із загальними мовними особливостями термінів і способами їх перекладу.

Дослідники термінології вважають, що саме на основі фахових текстів можна опрацьовувати дефініцію кожного терміна. Автентичні фахові тексти, на думку Г.А.Гринюк, є “джерелом словникового запасу студентів 3 фаху, прикладом вживання термінологічної лексики у контексті, що допомагає конкретизувати значення слів, пояснити й уточнити випадки їх вживання у відповідності до усталених мовних норм і стандартів. Тексти служать стимулом для інтелектуальної та мовленнєвої активності студентів під час інтерактивної комунікації на основі прочитаного" [2, с. 31]. Тому на кожному занятті ми намагаємось працювати 3 новими, цікавими, доступними за змістом і складністю текстами.

Основні завдання, що стоять перед студентами в процесі вивчення іноземної професійно-оріснтованої літератури:

1) отримання інформації, яка 6 доповнювала та поглиблювала навчальний матеріал, що опановується студентами в процесі вивчення профільних дисциплін навчального плану;

2) формування необхідних навичок щодо подальшого самостійного читання літератури за фахом [1, с. 76].

Більшість дослідників приходять до висновку, що тексти за спеціальністю вважаються не лише основним джерелом для накопичення фахового термінологічного словника студентів немовних ВН3, але й засобом становлення та розвитку їхньої професійної майстерності, сприяють підвищенню культури термінологічного спілкування та професійно орієнтованої ерудиції. Іншими словами, фахові тексти задовольняють інформаційно-пізнавальні потреби студентів, служать опорою для стимулювання навчальної мовленнєвої взаємодії студентів на професійну тематику, доповнюють їхні знання 3 фаху шляхом відтворення та смислової переробки отриманої інформації, розширюють комунікативну спроможність студентів до реального спілкування [2, с. 30].

Доведено, що вивчення термінологічної лексики відповідно до фахової підготовки студентів немовних факультетів, а відтак і формування їхньої іншомовної лексичної компетентності, буде тим успішнішим, чим краше зроблений відбір і методична класифікація лексичного матеріалу, що залучається до навчального процесу.

Розглянемо, яку саме фахову літературу доцільно використовувати під час відбору навчального матеріалу, необхідного для засвоєння термінологічної лексики студентами немовних факультетів, наприклад майбутніми економістами. Керуючись програмними вимогами та аналізом наукової літератури, вважаємо, що навчальний 
матеріал професійної сфери студентів-економістів передусім повинен базуватися на таких спеціальних англомовних текстах як монографії, матеріали наукових конференцій, публікації результатів теоретичних і експериментальних досліджень, аналітичні статті у періодичних фахових виданнях (наприклад, The World Economy, The Economist, The Economic Journal, Economic Notes, Oxford Economic Papers, Journal of Economics and Management Strategy та ін.) або в мережі Інтернет [5, с. 910]. Специфікою зазначених вище фахових текстів $\epsilon$ насиченість відповідними термінами, які розкривають наукові поняття і дають їм однозначне трактування. Такі тексти науково-економічного дискурсу $€$ інформативними й повноцінними щодо свого композиційного оформлення, чим забезпечується можливість для реального іншомовного спілкування і засвоєння спеціальної лексики.

Джерелом поповнення словникового запасу студентів-економістів $€$ також автентичні англомовні матеріали у формі ділових листів, контрактів, угод, декларацій, рекламних оголошень фірм і компаній, протоколів ділових зустрічей, прайс-листів, анотацій і звітів про виконання проектів тощо. Такі багатогранні автентичні матеріали містять виражену термінами фактологічну інформацію і $\epsilon$ зразками мовної норми іншомовного ділового стилю спілкування, а також несуть екстралінгвістичну інформацію, яка, як відомо, $є$ мотиваційним рушієм при навчанні іноземної мови [2, с. 31].

Окресливши тематику фахових текстів та відібравши термінологічну лексику для активного засвоєння студентами, потрібно створити комплекс вправ 3 метою вирішення комунікативних $\mathrm{i}$ пізнавальних задач під час роботи 3 фаховою літературою. Цей комплекс вправ можна поділити на дві групи:

1) лексико-граматичні вправи, які передбачають багаторазове виконання завдань одного типу i формують механізми читання 3 безпосереднім розумінням прочитаного;

2) вправи, які мають своїм об'єктом зміст наукового тексту, отримання фактичної інформації та іiі осмислення, а тому передбачають одночасне вирішення розумових завдань різного плану.

Робота над текстом за фахом починається 3 подачі та фонетичного опрацювання термінів і термінологічних словосполучень як ізольовано, так i в реченнях при виконанні умовно-мовленнєвих вправ рецептивного і репродуктивного характеру. Як показує практика, на початковому етапі вивчення англійської мови за професійним спрямуванням студенти більш зацікавлено й продуктивно опрацьовують термінологію сучасних текстів науково-популярного стилю. А студенти старших курсів, у яких уже сформовано предметно-понятійну базу, які розуміють терміни рідною мовою, опрацьовують самостійно термінологію 3 неадаптованих автентичних текстів наукового стилю. Такий вид читання необхідний студентам як для підготовки до написання рефератів, доповідей, так i для майбутнього професійного росту, поглиблення знань з фаху.

Отже, викладач іноземної мови повинен вирішити, який текст підібрати для читання на занятті. Ми вважаємо, що це має бути такий навчальний текст (професійно-орієнтований), насичений відповідною термінологією, адаптований до читання та обговорення, активного опрацювання на занятті, корисний та зрозумілий для студентів. Наприклад, для студентів-економістів використовуються такі тематичні тексти, як: Marketing; Accounting; Functions of Management; Marketing in Advertising; Financing a company; Inflation and Unemployment; Money and Banking; 
Demand, Supply and Elasticity; Business Meetings; Theory of the Consumer; Perfect Competition та ін.

Автентичні тексти за фахом мають бути не лише джерелом інформації, але й основою для інтерактивної мовленнєвої діяльності, матеріалом для моделювання навчально-мовленнєвих ситуацій, які характерні для реальної професійної діяльності фахівців. Від змісту відібраного автентичного матеріалу буде залежати, наскільки ефективно викладач зможе організувати навчальну діяльність на занятті, створити ситуації для пошуку та аналізу визначеної інформації, проконтролювати зміст висловлювань студентів і водночас розвивати їх аналітичне мислення, наукову здогадку, критичний підхід до вміщеної в текстах інформації.

Опрацювання термінологічної лексики при читанні фахових текстів відбувається у три етапи. Перший етап - презентація і семантизація термінологічної лексики. Це етап дотекстового опрацювання термінологічної лексики, на якому виконуються вправи на номінацію термінів, уміння оперувати термінами на рівні слова, словосполучення або речення [3]. Наприклад: Give equivalents to the following nouns/verbs; Give Ukrainian equivalents to the English verbs, using the cues; Match the word combinations from the left hand column with the right one; Read and translate the verbs, make up word combinations; Choose the right English equivalents to the Ukrainian words; Pick up a corresponding English verb; Substitute the verb by the synonymous one; Fill in the gaps with the words from the word list; Give synonyms / antonyms to the words; Match the correct definition with each word; Find the word that doesn't belong to the group; etc. Метою дотекстових вправ $є$ подача, семантизація та первинне закріплення термінологічної лексики. Основними завданнями вправ на цьому етапі роботи 3 фаховою лексикою $є$ допомогти студентам ідентифікувати й розуміти основні значення термінів, збагатити запас спеціальної лексики та підготувати студентів до опрацювання тексту.

Наступний етап навчання термінологічної лексики - подальше закріплення й автоматизація вживання термінологічних одиниць. На цьому етапі виконуються вправи на знаходження термінів у тексті, на побудову асоціативних зв'язків, на вміння оперувати термінами на рівні речення і надфразової єдності. Наприклад: Complete the following sentences; Fill in the right word into the sentences; Find the word that fit the definition below (all the required words are in the text); Use the following phrases to express agreement or disagreement; Match each term with its definition; Find Ukrainian equivalents to the English word combination; Read and translate the sentence; etc. Метою вправ текстового етапу є орієнтація студентів на пошук та сприйняття певної інформації у тексті, а також автоматизація дій з термінологічною лексикою. Основними завданнями цих вправ $є$ контроль процесу читання, мотивування до подальшої роботи з фаховим текстом з метою прогнозування змісту або вираження основної ідеї тексту, виходячи з термінологічної лексики. Виконуючи ці завдання, студенти переходять до вживання лексики на рівні автоматизму.

Останній (третій) етап - стан активізації та контролю засвоєння термінологічної лексики. На цьому етапі відбувається інтегрування сформованих автоматизмів та усвідомлене використання термінологічної лексики у мовленнєвій діяльності студентів на основі прочитаного. Студенти виконують післятекстові вправи на вміння осмисленого і творчого оперування термінами як в усному, так і писемному мовленні на рівні понадфразової єдності і тексту. Наприклад: Decide whether the following statements are true or false; Answer the following questions; Translate the text into English; Make a short report containing the information from the text; Make up 
dialogues based on the text. Work in pairs; Make up a short story answering the questions; Read the dialogue and trade role playing; Use the following sentences in your own dialogue. Work in pairs; Do two-way translation; Define which of the following items best completes the statement; Render the text into English; etc. Основною метою цих вправ $\epsilon$ підготовка студентів до продукування власних монологічних $\mathrm{i}$ діалогічних висловлювань по темі. Такі вправи стимулюють спілкування за проблематикою тексту з використанням термінів, допомагають їм узагальнювати факти і критично аналізувати прочитане. Для підтвердження й аргументації своєї думки студенти будуть читати інші тексти, шукатимуть додаткові джерела інформації.

Формулювання завдань дотекстових і післятекстових вправ повинні мати комунікативну спрямованість, викликати потребу в читанні запропонованого тексту, служити мотивом до спілкування, критичного мислення, до ініціювання складного висловлювання по темі прочитаного тексту, давати поштовх до формування та висловлювання власної думки, активізуючи при цьому термінологічну лексику.

Висновки і перспективи подальших наукових розвідок. Отже, можна зробити висновок, що читання і робота над фаховими текстами є основним джерелом для вивчення термінологічної лексики, яка пронизує весь курс англійської мови, $\mathrm{i}$ завдання викладача - знайти такі форми і методи іiі подачі та опрацювання, які б зробили цей процес цікавим і бажаним для студента. Перш за все - це використання сучасних інформаційних технологій, інтерактивних методів і прийомів навчання, які мотивуватимуть майбутніх фахівців до спілкування, дискусії, пошуку додаткової інформації, навчать чітко формулювати й висловлювати свою думку і позицію, сприймати й оцінювати інформацію, тобто активно вживати термінологічну лексику у будь-яких видах мовленнсвої діяльності. Приведені види вправ, безумовно, не вичерпують усього розмаїття форм і методів роботи студентів при вивченні фахової термінології. Багато питань розвитку навичок роботи з англомовними фаховими текстами ще чекають своєї розробки як в теоретичному, так і в практичному плані.

\section{Література}

1. Барабанова Г.В. Методика навчання професійно-орієнтованого читання у немовному ВНЗ / Г.В. Барабанова. - К.: Фірма "ІНКОС", 2005. - 315 с.

2. Кравчук Г.В. Навчання професійно-орієнтованого діалогічного мовлення на основі текстів науково-технічної реклами / Г.В. Кравчук // Іноземні мови. - 2008. - № 4. - С. 54 -57.

3. Кусько К.Я. Лінгвістика тексту за фахом // Лінгводидактична організація навчального процесу з іноземних мов у вузі: Колективна монографія. - Львів: "Світ", 1996. - 134 с.

4. Програма 3 англійської мови для професійного спілкування: English for Specific Purposes. National Curriculum for Universities / під ред. С.Ю. Ніколаєвої. - К.: Ленвіт, 2005. - 119 с.

5. Гринюк Г.А. Відбір навчального матеріалу для формування англомовної лексичної компетенції у студентів-економістів / Г.А.Гринюк, Ю.О Семенчук // Іноземні мови. - 2007. № 2 . - C. 30-34

6. Фоломкина С. К. Обучение чтению на иностранном языке в неязыковом вузе / С. К. Фоломкина. - М.: Высшая школа, 1987. - 328 с.

\section{References}

1. Barabanova, G.V. (2005). Metodyka navchannia profesiyno-oriyentovanogo chytannia V nemovnomu VNZ. Kyiv. INKOS. 315 p. [in Ukr].

2. Kravchuk, G.V. (2008). Navchannia profesiyno-oriyentovanogo dialogichnogo movlennia na osnovi textiv naukovo-tekhnichnoi reklamy. Foreign languages.4, pp. 54-57. [in Ukr]

3. Kusko, K.Ya. (1996). Linghvistyka tekstu za fakhom. Linghvodydaktychna orghanizacija navchalnogo procesu z inozemnykh mov u vuzi. Lviv: Svit. 134 p. [in Ukr].

4. Programa $z$ angliyskoi movy dlia profesiynoho spilkuvannia. English for Specific Purposes: (2005). Kyiv: Lenvit. 119 p. [in Ukr \& Engl] 
5. Gryniuk, G.A \& Semenchuk, Yu.O. (2007). Vidbir navchalnogo materialu dlia formuvannia anglomovnoi leksychnoi kompetentsii u studentiv-ekonomistiv. Foreign languages. 2, pp. 30-34. [in Ukr].

6. Folomkina, S.K. (1987). Obucheniye chteniyu na inostrannom yazyke v neyazykovom vuze. Moskva: Vysshaya shkola. 77 p. [in Rus].

Одержано статтю: 03.07.2019

Прийнято до друку: 17.07.2019

УДК [61:53(07)+577.3(07)]:37.026

DOI: $10.15330 / \mathrm{esu} .16 .205-213$

\section{Наталія Остапович,}

кандидат педагогічних наук, Івано-Франківський національний медичний університет (м. Івано-Франківськ, Україна)

Nataliia Ostapovych, Candidate of pedagogical sciences $(\mathrm{PhD})$, Ivano-Frankivsk National Medical University (Ivano-Frankivsk, Ukraine) nataost@windowslive.com

\section{Роман Лісовський,} кандидат фізико-математичних наук, Івано-Франківський національний медичний університет (м. Івано-Франківськ, Україна)

Roman Lisovskyi,

Candidate of physical and mathematical sciences $(\mathrm{PhD})$, Ivano-Frankivsk National Medical University (Ivano-Frankivsk, Ukraine) rlisovsky@ifnmu.edu.ua

\section{Лілія Туровська,} кандидат хімічних наук, Івано-Франківський національний медичний університет (м. Івано-Франківськ, Україна)

Liliia Turovska, Candidate of Chemical Sciences (PhD), Ivano-Frankivsk National Medical University (Ivano-Frankivsk, Ukraine) iturovska@ifnmu.edu.ua

\section{ВИКОРИСТАННЯ ДИДАКТИЧНИХ ІГОР ПЦД ЧАС ВИВЧЕННЯ ДИСДИПЛІН ПРИРОДНИЧОГО ЦИКЛУ У ПРОЦЕСІ ФАХОВОӤ ПІДГОТОВКИ МАЙБУТНІХ ЛIКАРІВ}

\section{THE USAGE OF DIDACTIC GAMES IN THE STUDY OF DISCIPLINES OF THE NATURAL CYCLE IN THE PROCESS OF PROFESSIONAL TRAINING OF FUTURE DOCTORS}

У статті розглянуто проблеми розробки методики навчания студентів медичної та біологічної фізики, вищої математики засобами ігрових навчальних технологій, з огляду на потреби сучасної професійної медичної освіти. Розроблено класифікацію ігрових технологій відповідно до ӥхньой домінуючой дидактичної мети, прочесуальної стратегї, рівня застосування; виду ігрового середовища. Досліджено дидактичний потенчіал ігрових технологій задля підвищення ефективності навчально-виховного прочесу засобами дидактичних ігор. Обірунтовано методику проведення та очінювання лабораторних робіт з медичної $i$ біологічної фізики з використанням дидактичних ігор та використання дидактичних ігор на лекиійних, семінарсъких, практичних заняттях з природничих 